\title{
HUBUNGAN DIMENSI KUALITAS PELAYANAN DENGAN KEPUASAN PASIEN RAWAT INAP PADA RSUP DR. TADJUDDIN CHALID MAKASSAR
}

\author{
Nurhasma1' Andi Syamsul Rijal2, Rahmawati Azis3 \\ 1 Sekolah Tinggi Ilmu Kesehatan Tamalatea Makassar, Indonesia \\ 2 Sekolah Tinggi Ilmu Ekonomi Makassar, Indonesia \\ 3 Sekolah Tinggi Ilmu Kesehatan Tamalatea Makassar, Indonesia
}

\begin{tabular}{ll}
\hline Article Info & ABSTRACT \\
\hline Article history: & $\begin{array}{l}\text { Abstract } \\
\text { Received 23-9-2021 }\end{array}$ \\
Revised 25-9-2021 & $\begin{array}{l}\text { Satisfaction in Hospitals in Indonesia. Patient satisfaction is one of the } \\
\text { critical indicators to control the quality of health services in hospitals. The }\end{array}$ \\
Accepted 26-11-2021 & study results indicate that the level of patient satisfaction in several hospitals \\
in Indonesia is still below the standard set by the government (>90\%). This
\end{tabular}

\begin{abstract}
Abstrak
Kualitas dalam suatu Pelayanan di Rumah Sakit sangat berhubungan dengan Kepuasan Pasien Rawat Inap di Rumah Sakit di Indonesia. Kepuasan pasien merupakan salah satu indikator penting untuk mengendalikan kualitas pelayanan kesehatan di rumah sakit. Dari hasil penelitian menunjukkan bahwa tingkat kepuasan pasien dibeberapa rumah sakit di Indonesia masih di bawah standar yang telah ditetapkan pemerintah (>90\%). Tujuan penelitian ini adalah untuk mengetahui hubungan dimensi kualitas pelayanan kesehatan dengan kepuasan pasien rawat inap di rumah sakit. Analisis data menggunakan analisis univariat, bivariat (uji Chi-Square) dan multivariat (uji Regresi Logistik). Hasil penelitian menunjukkan bahwa tingkat kepuasan pasien sebesar 96,6\%, ini berarti bahwa tingkat kepuasan pasien rawat inap di rumah sakit di Indonesia sudah baik karena sudah memenuhi standar kepuasan pelanggan yang ditetapkanoleh Kemenkes RI (>90\%). Analisis multivariat memperlihatkan adanya hubungan signifikan antara, pelayanan, lingkungan dan fasilitas Rumah Sakit. Hasil penelitian ini dapat disimpulkan bahwa kualitas pelayanan kesehatan yang diterima pasien sangat berpengaruh terhadap kepuasan pasien itu sendiri.
\end{abstract}

\section{Corresponding Author:}

Nama penulis, Nurhasma

Afiliansi Penulis, RSUD Tajuddin Makassar

Alamat Penulis, BTN Nusa Harapan Permai Blok A3/25

Email: penulis, nurhasma.usman@gmail.com 


\section{PENDAHULUAN}

Rumah sakit sebagai tingkat pelayanan lanjutan setelah puskesmas tentunya harus mempunyai pelayanan yang lebih baik. bukan hanya sebagai penunjang kesehatan di dalam wilayah kecil seperti kecamatan, namun dalam cakupan lebih luas seperti kabupaten ataupun kota. Seseorang yang datang berobat ke rumah sakit mempunyai harapan tinggi akan pelayanan kesehatan yang diberikan. Karena masyarakat beranggapan kualitas pelayanan rumah sakit pasti berkualitas dengan didukung fasilitas, sumber daya manusia di rumah sakit lebih bisa menanggulangi masalah kesehatan mereka [1]

Pelayanan kesehatan di rumah sakit merupakan bentuk pelayanan yang diberikan kepada pasien oleh suatu tim multi disiplin. Tim kesehatan garda depan yang menghadapi masalah pasien selama 24 jam secara terus menerus. Pelayanan yang diberikan garda depan tentunya akan menjadi kepuasan tersendiri bagi pasien dalam menjalani perawatan rawat inap di RS. Kepuasan adalah perasaan senang seseorang yang berasal dari perbandingan antara kesenangan terhadap aktivitas dan suatu layanan produk dengan harapannya yaitu kepuasan. Kepuasan pasien ini dapat tercipta melalui pelayanan yang baik oleh para tenaga medis yang ada di instansi kesehatan. Dengan demikian bila pelayanan kurang baika maka pasien yang merasa tidak puas akan mengajukan komplain pada pihak rumah sakit. Komplain yang tidak segera ditangani akan mengakibatkan menurunnya minat pasien untuk berobat [2]

Kualitas pelayanan di rumah sakit menjadi salah satu faktor penting dalam memenuhi hak masyarakat untuk kesehatan. Di sisi lain, kualitas pelayanan di rumah sakit tampil dengan fenomena yang unik, karena dimensi dan indikator yang berbeda antara orang-orang yang terlibat dalam pelayanan. Untuk mengatasi perbedaan tersebut, seharusnya digunakan pedoman dasar penyelenggaraan pelayanan kesehatan yang memenuhi kebutuhan dan tuntutan para pemakai jasa pelayanan kesehatan. Mutu pelayanan terarah pada pelayanan kesehatan yang sempurna dalam memenuhi kebutuhan dan tuntutan setiap pasien. Dengan demikian, mutu pelayanan kesehatan adalah segala yang menunjukkan tingkat kesempurnaan pelayanan kesehatan yang menimbulkan rasa puas pada diri setiap pasien, [3]

Kepuasan pasien terhadap pelayanan kesehatan yang diberikan dipengaruhi oleh kepuasan terhadap pelayanan lingkungan dan fasilitas yang tersedia [4]. Hal ini berarti bahwa semakin baik pelayanan kesehatan yang diberikan oleh sebuah rumah sakit maka diharapkan semakin memuaskan pasien sebagai penerima layanan, meskipun pada dasarnya kepuasan pasien atas pelayanan yang diberikan merupakan nilai subjektif terhadap kualitas pelayanan yang diberikan dan diterima oleh pasien. Meskipun nilai subjektif ini sangat dipengaruhi oleh berbagai faktor akan tetapi kepuasan pasien tetap akan didasari oleh kebenaran dan kenyataan objektif yang dialami oleh pasien saat menerima pelayanan di rumah sakit. Kepuasan merupakan pernyataan psikologi yang dihasilkan dari terpenuhi atau tidaknya harapan dengan pelayanan yang diterima secara nyata, [5]

Kepuasan pasien berkorelasi dengan mutu pelayanan di rumah sakit. Dengan memahami tingkat kepuasan pasien, manajemen rumah sakit dapat mempelajari dan melakukan peningkatan mutu pelayanan. Penentuan kepuasan pasien diukur menggunakan instrumen baku berdasarkan indikator kinerja rumah sakit Departemen Kesehatan Republik Indonesia tahun 2005 Nursalam [6]. Kepuasan pasien merupakan suatu sikap. Walaupun hal ini belum bisa membuat pasien untuk tetap loyal kepada dokter atau rumah sakit, tetapi hal ini merupakan faktor penng. Kepuasan pasien adalah salah satu indikator dak langsung terhadap kualitas dokter atau rumah sakit. Pelayanan terhadap pasien yang disediakan harus dengan sepenuh ha, bukan kadang-kadang tapi selalu. Sehingga hal ini dapat diterapkan kepada seap pasien seap waktu [7]

Rumah sakit sebagai penyedia layanan keperawatan perlu terus melakukan upaya-upaya untuk meningkatkan kualitas pelayanan karena jika pelayanan yang diberikan dianggap tidak memuaskan oleh pasien maka ada kemungkinan pasien tersebut akan mencari rumah sakit lain yang dianggap lebih baik mengingat jumlah sarana pelayanan kesehatan juga semakin lama semakin bertambah. RSUP dr. Tadjuddin Chalid Makassar merupakan salah satu rumah sakit yang berada di wilayah Kota Makassar dengan lokasi tidak jauh di pinggir jalan Propinsi. Kondisi ini dari segi lokasi memudahkan untuk dijangkau sehingga masyarakat dapat saja dengan mudah memanfaatkan pelayanan yang disediakan oleh rumah sakit tersebut. Tetapi karena RSUP dr.Tadjuddin Chalid Makassar tersebut berada juga dekat dengan beberapa rumah sakit yang ada di kota tersebut, maka hal ini merupakan tantangan dalam memberikan pelayanan. Jika pelayanan yang diberikan dianggap kurang memuaskan oleh pengguna layanan dapat saja pasien-pasien yang ada justru lebih memilih rumah sakit yang berada di Kota Makassar karena jaraknya tidak begitu jauh dan mudah dijangkau apalagi jika pelayanan yang diberikan dianggap lebih baik dan memuaskan.

Sebagai upaya pemberian layanan kepada pasien, pihak Badan Pengelola RSUP dr. Tadjuddin Chalid Makassar telah mengupayakan peningkatan kualitas layanan melalui penyediaan fasilitas yang memadai, petugas kesehatan yang terampil dan berdedikasi tinggi terhadap tugas serta koordinasi dengan semua pihak yang terkait. Berdasar gambaran tersebut maka dipandang penting untuk menggali permasalahan terkait dengan kualitas pelayanan dengan kepuasan pasien rawat inap RSUP dr. Tajuddin Chalid Makassar.

Bila pasien merasa puas dengan pelayanan yang diterima ada kemungkinan untuk kembali menggunakan jasa pelayanan keperawatan selanjutnya. Untuk itu kepuasaan pasien merupakan salah satu indikator penting dalam pemberian pelayanan Kesehatan pasien, agar pasien dapat melakukan proses pengobatan secara berkelanjutan [4]. 
Pemberian mutu pelayanan kesehatan yang diberikan secara efisien dan efektif, berfokus kepada kebutuhan dan harapan pasien, dan diberikan sesuai kode etik, standar pelayanan kesehatan, perkembangan ilmu pengetahuan, sehingga derajat kesehatan bisa tercapai dengan optimal. Selain itu mutu pelayanan kesehatan dengan kepuasan pasien difokuskan pada 5 dimensi yang dikenal dengan istilah mutu layanan, [8]. Mutu layanan dimaksud yaitu; bukti fisik (tangible), empati (empathy), jaminan (ssurance), daya tanggap (responsiveness) dan kehandalan (reliability). Pasien dikatakan puas ketika harapan pasien dapat terpenuhi melalui jasa pelayanan kesehatan yang diterima dirumah sakit karena tuntutan kebutuhan pasien semakin meningkat. Sebagaimana hasil penelitian sebelumnya mengatakan bahwa, ada hubungan signifikan antara mutu pelayanan keperawatan dan tingkat kepuasan pasien rawat inap di RSUD Pandan. Sejalan dengan itu Juita et all, menjelaskan bahwa ada hubungan antara mutu pelayanan dan kepuasan pasien, dilihat dari dimensi bukti fisik, empati, daya tanggap, jaminan, dan kehandalan. Sedangkan penelitian yang dilakukan Kosnan (, mengungkapkan bahwa terdapat pengaruh signifikan antara bukti fisik, empati, jaminan, daya tanggap dan kehandalan dengan kepuasan pasien. Menurut beberapa hasil penelitian di atas, disimpulkan bahwa mutu pelayanan ditinjau dari 5 dimensi berpengaruh terhadap kepuasan pasien, dimana semakin baik mutu pelayanan kesehatan yang diberikan rumah sakit maka kepuasan pasien akan semakin meningkat [8]

Strategi pelayanan prima setiap rumah sakit harus melakukan pendekatan mutu paripurna yang berorientasi pada kepuasan pasien, agar rumah sakit tetap eksis, ditengah pertumbuhan industri pelayanan kesehatan yang semakin kuat. Upaya rumah sakit untuk tetap bertahan dan berkembang adalah dengan meningkatkan pelayanan kepada pasien. Hal tersebut karena pasien merupakan sumber pendapatan yang ditunggu oleh rumah sakit, baik secara langsung (out of pocket) maupun secara tidak langsung melalui asuransi kesehatan. Tanpa pasien, rumah sakit tidak dapat bertahan dan berkembang mengingat besarnya biaya operasional rumah sakit yang tinggi. Rumah Sakit melakukan berbagai cara demi meningkatnya kunjungan pasien, sehingga rumah sakit harus mampu menampilkan dan memberikan pelayanan kesehatan, sehingga dari dampak yang muncul akan menimbulkan sebuah loyalitas pada pasien sehingga pasien akan datang kembali memanfaatkan jasa rumah sakit tersebut. Bagi rumah sakit memuaskan kebutuhan pasien berarti perusahaan harus memberikan pelayanan berkualitas (service quality) kepada pasien, [9]. Berdasarkan penelitian oleh peneliti pendahulu diantaranya, menemukan kualitas pelayanan berpengaruh positif dan signifikan terhadap kepuasan. Hal ini mempunyai arti peningkatan kualitas layanan akan meningkatkan kepuasan [10], demikian juga sebaliknya apabila kualitas layanan menurun maka kepuasan pasien juga akan menurun, dengan demikian kualitas pelayanan medis, kualitas pelayanan para medis dan kualitas pelayanan penunjang medis memiliki pengaruh yang signifikan dan positif terhadap kepuasan pasien. [9]

Mutu pelayanan kesehatan adalah yang menunjuk pada tingkat kesempurnaan pelayanan kesehatan, yang disuatu pihak dapat menimbulkan kepuasan kepada setiap pasien sesuai dengan tingkat kepuasan rata-rata penduduk, serta dipihak lain tata cara penyelenggaraan sesuai dengan kode etik dan standar pelayanan profesi yang telah ditetapkan. Adapun Indikator yang dapat digunakan dalam menilai jasa pelayanan kesehatan antara lain; a) Indikator klinik, b) Indikator efisiensi, c) Indikator keamanan pasien, d) Indikator kepuasan pasien, [4]

Pengukur tingkat kepuasan pasien dapat digunakan sebagai alat untuk: 1) evaluasi kualitas pelayanan kesehatan, 2) evaluasi terhadap konsultasi intervensi dan hubungan antara perilaku sehat dan sakit, 3) membuat keputusan administrasi, 4) evaluasi efek dari perubahan organisasi pelayanan, 5) administrasi staf, 6) fungsi pemasaran, 7) formasi etik professional, [11]

Berdasar dari indikator di atas, menjadi dasar pengukuran mengenai tingkat kepuasaan pasien terhadap pelayanan rawat inap RSUP dr. Tadjuddin Chalid Makassar. Kepuasan merupakan sesuatu yang sifatnya subjektif, semakin baik pelayanan kesehatan yang diberikan oleh sebuah Rumah Sakit maka diharapkan semakin memuaskan pasien sebagai penerima layanan, meskipun pada dasarnya kepuasan klien atas pelayanan yang diberikan merupakan nilai subjektif terhadap kualitas pelayanan yang diberikan dan diterima oleh klien. Meskipun nilai subjektif ini sangat dipengaruhi oleh berbagai faktor akan tetapi kepuasan klien tetap akan didasari oleh kebenaran dan kenyataan objektif yang dialami oleh klien saat menerima pelayanan di Rumah Sakit.

Kepuasan pasien terhadap pelayanan kesehatan yang diberikan dipengaruhi oleh kepuasan terhadap pelayanan (medis, keperawatan, gizi, laboratorium, radiologi, administrasi), lingkungan dan fasilitas yang tersedia [12]. Pelayanan yang baik sesuai dengan standar yang diharapkan oleh pengguna jasa pelayanan, lingkungan Rumah Sakit yang tenang dan nyaman serta ketersediaan fasilitas yang memadai akan membuat pasien mengungkapkan rasa puas terhadap pelayanan yang diberikan. Ukuran yang bisa digunakan jika pasien dianggap puas dengan pelayanan yang diberikan adalah jika pasien tersebut akan kembali memanfaatkan layanan yang diberikan.

\section{METODE PENELITIAN}

Jenis penelitian yang digunakan adalah penelitian deskriptif yaitu menjelaskan sesuatu atau beberapa keadaan [12]. Penelitian ini menggunakan rancangan cross sectional yaitu mengungkapkan hubungan antara Jurnal Kesehatan Masyarakat, Vol. 07, No. 2, 2021: 90-100 
variabel independen dengan variabel dependen [13]. Penelitian ini dilakukan untuk melihat faktor-faktor yang mempengaruhi kepuasan pasien di ruang rawat inap Badan Pengelola RSUP dr Tajuddin Chalid Makassar.

Penelitian ini akan dilaksanakan di Badan Pengelola Badan Pengelola RSUP dr Tajuddin Chalid Makassar pada bulan Juni 2021. Adapun jumlah Populasi adalah keseluruhan dari suatu variabel yang menyangkut masalah yang diteliti [13]. Pada penelitian ini populasinya adalah semua pasien di ruang rawat inap Badan Pengelola RSUP dr Tajuddin Chalid Makassar sedangkan Sampelnya adalah sebagian dari keseluruhan objek yang diteliti dan dianggap mewakili seluruh populasi [14]. Dalam penelitian ini jumlah sampel yang digunakan sebanyak 60 Responden dengan menggunakan teknik non probability sampling melalui Kriteria Inklusi 1) Pasien dirawat di ruang rawat inap, 2)Telah menjalani perawatan minimal 3 hari, 3) Pasien dengan kesadaran yang baik, 4) Bisa baca tulis, 5) Bersedia berpartisipasi dalam penelitian. Sedangkan Kriteria eksklusi 1) Pasien rawat jalan, 2) Lama perawatan kurang dari 3 hari, 3) Pasien dengan penurunan kesadaran, 4) Tidak bisa baca tulis, 5) Tidak bersedia berpartisipasi dalam penelitian.

Teknik analisis data yang digunakan ada dua yaitu Analisa data univariat dan analisis multivariat. Analisis unviariat mencakup 1) Kepuasan Pasien, 2) Pelayanan Rumah Sakit, 3) Lingkungan Rumah Sakit dan 4) Fasilitas Rumah Sakit. Sedangkan analisis multivariat dilakukan untuk menilai hubungan dua variabel, dalam hal ini hubungan antara faktor pelayanan, lingkungan dan fasilitas rumah sakit dengan kepuasan pasien rawat inap. Untuk pengujian hipotesis Uji hipotesis menggunakan Chi Square dalam SPSS 12 dengan nilai $\alpha=0,05$ dan daerah kritis $\mathrm{H}_{0}$ ditolak jika Sig < $\alpha$ [15].

\section{HASIL DAN PEMBAHASAN}

Hasil penilitian yang telah diuji menggunakan statistik sehingga didapatkan hasil penelitian mengenai Dimensi Kwalitas Pelayanan Terhadap Kepuasan Pasien Rawat Inap Pada RSUP dr. Tadjuddin Chalid Makassar. Hasil penelitian diawali dengan pengumpulan karakteristik responden berdasarkan jenis kelamin, kelompok umur dan tingkat pendidikan sebagai berikut:

Tabel 1. Distribusi Frekuensi Responden Berdasarkan Jenis Kelamin di Ruang Rawat Inap Badan Pengelola RSUP dr Tajuddin Chalid Makassar

\begin{tabular}{|c|c|c|c|}
\hline NO & Jenis Kelamin & f & $\%$ \\
\hline 1 & Laki - Laki & 28 & 46,7 \\
\hline 2 & Perempuan & 32 & 53,3 \\
\hline & Jumlah & 60 & 100,0 \\
\hline
\end{tabular}

(Sumber: Data Primer,2021)

Berdasarkan tabel 1 dapat diketahui bahwa dari 60 responden lebih banyak berjenis kelamin perempuan $(53,3 \%)$ dibandingkan dengan laki-laki $(46,7 \%)$.

Tabel 2

Distribusi Frekuensi Responden Berdasarkan Umur dan tingkat pendidikan di Ruang Rawat Inap Badan Pengelola RSUP dr Tajuddin Chalid Makassar

\begin{tabular}{|c|c|c|c|c|c|c|}
\hline NO & Umur & F & $\%$ & Pendidikan & F & $\%$ \\
\hline 1 & $16-25$ tahun & 13 & 21,7 & SD & 21 & 35,0 \\
\hline 2 & $26-35$ tahun & 15 & 25,0 & SMP & 9 & 15,0 \\
\hline 3 & $36-45$ tahun & 15 & 25,0 & SMA & 28 & 46,7 \\
\hline 4 & $46-55$ tahun & 7 & 11,5 & S1 & 2 & 3,3 \\
\hline 5 & $56-65$ tahun & 3 & 5,0 & & & \\
\hline 6 & $\geq 66$ tahun & 7 & 11,8 & & & \\
\hline & Jumlah & 60 & 100,0 & Jumlah & 60 & 100,0 \\
\hline
\end{tabular}

(Sumber : Data Primer, 2021)

Bedasarkan Tabel 2 dijelaskan bahwa responden berumur 26-35 tahun dan 36-45 tahun masing-masing 25\%. Responden yang paling sedikit berumur antara 56-65 tahun (5\%). Terdapat juga responden berusia $\geq 66$ tahun sebanyak $11,8 \%$. Sedangkan menurut kategori tingkat pendidikan, yang terbanyak adalah pendidikan SD (35\%), SMP (15\%), SMA $(46,7 \%)$, dan S1 $(3,3 \%$

Jurnal Kesehatan Masyarakat, Vol. 07, No. 2, 2021: 90-100 
Berdasarkan analisis Univariat diperoleh hasil penelitian yang digambarkan pada tebel berikut:

Tabel 3

Distribusi Frekuensi Responden Berdasarkan Kepuasan Pasien, pelayanan rumah sakit, lingkungan rumah sakit dan

fasilitas rumah sakit yang di rawat di Ruang Rawat Inap Badan Pengelola RSUP dr Tajuddin Chalid Makassar

\begin{tabular}{|c|c|c|c|c|c|c|c|c|c|c|c|c|}
\hline $\mathrm{NO}$ & $\begin{array}{c}\text { Kepuasan } \\
\text { Pasien }\end{array}$ & $\mathrm{F}$ & $\%$ & $\begin{array}{c}\text { Pelayanan } \\
\text { Rumah Sakit }\end{array}$ & $\mathrm{f}$ & $\%$ & $\begin{array}{c}\text { Lingkungan } \\
\text { Rumah } \\
\text { Sakit }\end{array}$ & $\mathrm{F}$ & $\%$ & $\begin{array}{c}\text { Fasilitias } \\
\text { Rumah } \\
\text { Sakit }\end{array}$ & $\mathrm{f}$ & $\%$ \\
\hline 1 & Puas & 54 & 90,0 & Baik & 57 & 95,0 & Baik & 45 & 75,0 & Cukup & 46 & 76,7 \\
\hline 2 & $\begin{array}{l}\text { Tidak } \\
\text { Puas }\end{array}$ & 6 & 10,0 & Kurang & 3 & 5,0 & Kurang & 15 & 25,0 & Kurang & 14 & 23,3 \\
\hline & Jumlah & 60 & 100,0 & Jumlah & 60 & 100,0 & Jumlah & 60 & 100,0 & & & \\
\hline
\end{tabular}

(Sumber : Data Primer, 2021)

Berdasarkan tabel 3 diketahui bahwa pada umumnya responden menyatakan puas terhadap pelayanan yang diberikan di Badan Pengelola Rumah Sakit Ruang Rawat Inap RSUP dr Tajuddin Chalid Makassar dengan nilai puas $90 \%$ dan tidak puas $10 \%$. Terkait dengan pelayanan rumah sakit pada umumnya responden menyatakan pelayanan Ruang Rawat Inap Badan Pengelola RSUP dr Tajuddin Chalid Makassar baik (95\%) meskipun ada juga yang menyatakan pelayanan masih kurang (5,0\%). Penilaian responden terhadap lingkungan Rumah Sakit pada umumnya baik (75\%). Sebagian responden juga menilai lingkungan Rumah Sakit kurang (25\%). umumnya responden menilai fasilitas Rumah Sakit cukup (76,7\%). Sebagian responden menilai fasilitas Rumah Sakit kurang $(23,3 \%)$.

1. Analisis Bivariat

a. Hubungan Pelayanan RS dengan Kepuasan Pasien

Kepuasan pasien merupakan hal yang bersifat subjektif. Dalam penelitian ini digunakan tiga faktor yang berhubungan dengan kepuasan pasien meliputi faktor pelayanan Rumah Sakit, lingkungan Rumah Sakit dan fasilitas Rumah Sakit. Hasil pengumpulan data dan analisa data menunjukkan hubungan berbagai hal yang berkaitan dengan kepuasan pasien yang dirawat di Ruang Rawat Inap Badan Pengelola RSUP dr Tajuddin Chalid Makassar dalam tabel sebagai berikut :

Tabel 4

Hubungan Pelayanan RS dengan Kepuasan Pasien di Ruang Rawat Inap Badan Pengelola RSUP dr Tajuddin Chalid Makassar

\begin{tabular}{|c|c|c|c|c|c|c|c|}
\hline \multirow{2}{*}{$\begin{array}{c}\text { PELAYANAN } \\
\text { RS }\end{array}$} & \multicolumn{4}{|c|}{ Kepuasan Pasien } & \multicolumn{2}{c|}{ TOTAL } & \\
\cline { 2 - 7 } & \multicolumn{2}{|c|}{ Puas } & \multicolumn{2}{c|}{ Tidak puas } & \multicolumn{2}{c|}{} & \multirow{2}{*}{$P$} \\
\cline { 2 - 8 } & $\mathrm{f}$ & $\%$ & $\mathrm{~F}$ & $\%$ & $\mathrm{f}$ & $\%$ & \\
\hline Cukup & 54 & 90,0 & 3 & 5,0 & 57 & 95,0 & \multirow{2}{*}{0,00} \\
\hline Kurang & 0 & 0,0 & 3 & 5,0 & 3 & 5,0 & \\
\hline Jumlah & 54 & 90,0 & 6 & 10,0 & 60 & 100,0 & \\
\hline
\end{tabular}

(Sumber : Data Primer, 2021)

Berdasarkan tabel 4.8 didapakan data bahwa dalam pelayanan rumah sakit umumnya responden yang menyatakan pelayanan Rumah Sakit cukup juga menyatakan puas $(90 \%)$ dan ada juga yang menyatakan pelayanan cukup tetapi tidak puas (5\%). Yang menyatakan pelayanan kurang juga tidak puas (5\%). Setelah dianalisa dengan menggunakan uji Chi Square di peroleh nilai hitung $p=0,00$ lebih kecil dari nilai $\alpha=0,05$ artinya ada hubungan antara pelayanan RS dengan kepuasan pasien 
b. Hubungan Lingkungan RS dengan Kepuasan Pasien

Tabel 5

Hubungan Lingkungan RS dengan Kepuasan Pasien di Ruang Rawat Inap Badan Pengelola RSUP dr Tajuddin Chalid Makassar

\begin{tabular}{|c|c|c|c|c|c|c|c|}
\hline \multirow{3}{*}{$\begin{array}{c}\text { LINGKUNGAN } \\
\text { RS }\end{array}$} & \multicolumn{4}{|c|}{ Kepuasan Pasien } & \multirow{2}{*}{\multicolumn{2}{|c|}{ TOTAL }} & \multirow{3}{*}{$P$} \\
\hline & \multicolumn{2}{|c|}{ Puas } & \multicolumn{2}{|c|}{ Tidak puas } & & & \\
\hline & $f$ & $\%$ & $\mathrm{f}$ & $\%$ & $\mathrm{f}$ & $\%$ & \\
\hline Baik & 44 & 73,0 & 1 & 2,0 & 45 & 75,0 & \\
\hline Kurang & 10 & 16,6 & 5 & 8,4 & 15 & 25,0 & 0,01 \\
\hline Jumlah & 54 & 89,6 & 6 & 10,4 & 60 & 100,0 & \\
\hline
\end{tabular}

(Sumber : Data Primer, 2021)

Berdasarkan dari tabel 4.9 Responden yang menyatakan lingkungan Rumah Sakit baik umumnya juga menyatakan puas $(73 \%)$ meskipun ada juga yang menyatakan linkungan Rumah Sakit baik tetapi tidak puas serta lingkungan kurang tapi menyatakan puas. Setelah dianalisa dengan menggunakan uji Chi Square di peroleh nilai hitung $p=0,01$ lebih kecil dari nilai $\alpha=0,05$ artinya ada hubungan antara lingkungan RS dengan kepuasan pasien.

Hubungan Fasilitias RS dengan Kepuasan Pasien

Tabel 6

Hubungan Lingkungan RS dengan Kepuasan Pasien di Ruang Rawat Inap Badan Pengelola RSUP dr Tajuddin Chalid Makassar

\begin{tabular}{|c|c|c|c|c|c|c|c|}
\hline \multirow{2}{*}{$\begin{array}{c}\text { FASILITAS } \\
\text { RS }\end{array}$} & \multicolumn{4}{|c|}{ Kepuasan Pasien } & \multicolumn{2}{c|}{ TOTAL } & \multirow{2}{*}{$P$} \\
\cline { 2 - 7 } & \multicolumn{2}{|c|}{ Puas } & \multicolumn{2}{c|}{ Tidak puas } & & \\
\cline { 2 - 7 } & $\mathrm{f}$ & $\%$ & $\mathrm{~F}$ & $\%$ & $\mathrm{f}$ & $\%$ & \\
\hline Cukup & 44 & 73 & 2 & 3,3 & 46 & 76,7 & \\
\hline Kurang & 10 & 16,6 & 4 & 6,7 & 14 & 23,3 & \\
& & & & & & & \\
\hline Total & 54 & 89,6 & 6 & 10,0 & 60 & 100,0 & \\
\hline
\end{tabular}

(Sumber : Data Primer, 2021)

Berdasarkan tabel 4.10 Penilaian terhadap fasilitas Rumah Sakit menunjukkan bahwa umumnya yang menyatakan fasilitas baik juga puas $(73 \%)$ tetapi ada juga yang berpendapat fasilitas kuranng tetapi puas dengan pelayanan $(3,3 \%)$. Selain itu terdapat juga responden yang menyatakan pelayanan kurang tetapi tetap puas dengan pelayanan (16,6\%). Setelah dianalisa dengan menggunakan uji Chi Square di peroleh nilai hitung $p=0,08$ lebih besar dari nilai $\alpha=0,05$ artinya tidak ada hubungan signifikan antara fasilitas RS dengan kepuasan pasien.

2. Analisis Multivariat

Analisis regresi linier berganda adalah hubungan secara linier antara dua atau lebih variabel independen dengan variable dependen. Analisis ini untuk mengetahui arah hubungan antara variabel independen dan variabel dependen berhubungan positif atau negatif dan untuk memprediksi nilai dari variable dependen apabila variabel independen mengalami kenaikan atau penurunan. Analisis regresi linear berganda dilakukan dengan cara menetapkan persamaan $\hat{\mathrm{Y}}=\mathrm{a}+\mathrm{b} 1 \mathrm{X} 1+\mathrm{b} 2 \mathrm{X} 2+\mathrm{b} 3 \mathrm{X}_{3}+\mathrm{e}$ Hasil perhitungan nilai-nilai sebagai berikut: $\hat{\mathrm{Y}}=-1.105+0.762 \mathrm{X} 1+0.152 \mathrm{X} 2+0.143 \mathrm{X}_{3}+\mathrm{e}$ Yang memiliki arti 
a. Nilai konstanta $\mathrm{a}=-1.105$ artinya jika variable pelayanan $\mathrm{RS}$, lingkungan $\mathrm{RS}$, dan fasilitas RS tidak dimasukkan dalam penelitian maka kepuasan pasien di Ruang Rawat Inap Badan Pengelola RSUP dr Tajuddin Chalid Makassar sebesar $-1.105 \%$.

b. Nilai koefisien b1 $=0.762$ artinya jika variable pelayanan RS ditingkatkan lebih baik lagi maka kepuasan pasien di Ruang Rawat Inap Badan Pengelola RSUP dr Tajuddin Chalid Makassar akan meningkat sebesar $0.762 \%$ dengan ansumsi variabel independent yang lain konstan.

c. Nilai kofisien b2 $=0.152$ artinya jika variabel lingkungan RS ditingkatkan $1 \%$ lebih baik lagi maka kepuasaan pasien di Ruang Rawat Inap Badan Pengelola RSUP dr Tajuddin Chalid Makassar akan meningkat sebesar $0.152 \%$ dengan asumsi variabel independent yang lain konstan.

d. Nilai kofisien b3 $=0.143$ artinya jika variabel fasilitas RS ditingkatkan $1 \%$ lebih baik lagi maka kepuasaan pasien di Ruang Rawat Inap Badan Pengelola RSUP dr Tajuddin Chalid Makassar akan meningkat sebesar $0.143 \%$ dengan asumsi variabel independent yang lain konstan.

1) Uji T

Uji T dalam regresi linier berganda dimaksudkan untuk menguji apakah parameter (koefisien regresi dan konstanta) yang diduga untuk mengestimasi persamaan/model regresi linier berganda sudah merupakan parameter yang tepat atau belum. Maksud tepat disini adalah parameter tersebut mampu menjelaskan perilaku variabel bebas dalam mempengaruhi variabel terikatnya. Parameter yang diestimasi dalam regresi linier meliputi intersep (konstanta) dan slope (koefisien dalam persamaan linier). Pada bagian ini, uji t difokuskan pada parameter slope (koefisien regresi) saja. Jadi uji t yang dimaksud adalah uji koefisien regresi. Ketentuan yang digunakan adalah apabila nilai probabilitas lebih kecil dari pada 0.05 maka H0 ditolak atau koefisien regresi signifikan, dan apabila nilai probabilitas lebih besar dari 0.05 maka H0 diterima atau koefisien regresi tidak signifikan. Rumus pengambilan t tabel dengan nilai signifikan 5\% adalah sebagai berikut :

T tabel $=\mathrm{n}-\mathrm{k}-1: 0,05 / 2$

$\mathrm{T}$ tabel $=60-3-1: 0,05 / 2$

$\mathrm{T}$ tabel $=2.003$

Berdasarkan Hasil uji t tersebut dapat dilihat pada tabel 4.11, yakni :

a) Nilai koefisien regresi variabel pelayanan $\mathrm{RS}$ ( $\mathrm{t}$ hitung) adalah sebesar 5,496 dengan t tabel sebesar 2.003, signifikasi variabel pelayanan RS terhadap variabel terkait yaitu kepuasan pasien sebesar 0,000 atau lebih kecil dari nilai alpha 0,05. Kesimpulannya nilai $\mathrm{t}$ hitung $>\mathrm{t}$ tabel dan signifikasi $0,009<0,05$ artinya variabel pelayanan RS berpengaruh signifikan terhadap kepuasan pasien atau Ha diterima dan $\mathrm{H} 0$ ditolak.

b) Nilai koefisien regresi variabel lingkungan RS (t hitung) adalah sebesar 2,245 dengan t tabel sebesar 2.003, signifikasi variabel pelayanan RS terhadap variabel terkait yaitu kepuasan pasien sebesar 0,029 atau lebih kecil dari nilai alpha 0,05. Kesimpulannya nilai $\mathrm{t}$ hitung $>\mathrm{t}$ tabel dan signifikasi $0,029<0,05$ artinya variabel lingkungan RS berpengaruh signifikan terhadap kepuasan pasien atau Ha diterima dan $\mathrm{H} 0$ ditolak.

c) Nilai koefisien regresi variabel lingkungan $\mathrm{RS}$ ( $\mathrm{t}$ hitung) adalah sebesar 2,177 dengan t tabel sebesar 2.003, signifikasi variabel pelayanan RS terhadap variabel terkait yaitu kepuasan pasien sebesar 0,034 atau lebih kecil dari nilai alpha 0,05. Kesimpulannya nilai $t$ hitung $>\mathrm{t}$ tabel dan signifikasi $0,034<0,05$ artinya variabel fasilitas RS berpengaruh signifikan terhadap kepuasan pasien atau Ha diterima dan $\mathrm{H} 0$ ditolak.

2) $\mathrm{Uji} F$

Uji ini dimaksudkan untuk mengetahui ada tidaknya pengaruh variabel independen secara bersama-sama dengan variabel dependen. Uji ini disebut juga dengan istilah uji kelayakan model atau yang lebih populer disebut sebagai uji simultan model. Uji ini mengidentifikasi model regresi yang diestimasi layak atau tidak. Layak disini maksudnya adalah model yang diestimasi layak digunakan untuk menjelaskan pengaruh variabel-variabel bebas terhadap variabel terikat. Ketentuan yang diberlakukan adalah apabila nilai prob. F hitung (ouput hasil ditunjukkan pada kolom sig.) lebih kecil dari tingkat kesalahan/error (alpha) 0,05 (yang telah ditentukan) maka Ho ditolak atau dapat dikatakan bahwa model regresi yang diestimasi layak, sedangkan apabila nilai prob. $\mathrm{F}$ hitung lebih besar dari tingkat kesalahan 0,05 maka dapat dikatakan H0 diterima jika nilai $\mathrm{f}$ hitung $\leq \mathrm{f}$ tabel dan signifikasi $>0,05$. Dan H3 diterima jika variabel kepemimpinan dan motivasi kerja secara bersama-sama memiliki nilai $\mathrm{f}$ hitung $\geq \mathrm{f}$ tabel dan signifikasi $<0,05$. nilai $\mathrm{F}$ hitung sebagai berikut : Rumus F hitung yakni :

$\mathrm{F}$ tabel $=\mathrm{Df}=\mathrm{k} ; \mathrm{n}-\mathrm{k}$

$\mathrm{F}$ tabel $=\mathrm{Df}=3 ; 60-3$

$\mathrm{F}$ tabel $=2.77$

Jurnal Kesehatan Masyarakat, Vol. 07, No. 2, 2021: 90-100 
Hasil analisis Anova menunjukkan nilai F 22,677 > nilai f tabel 2,77 dan signifikasi 0,000<0,05 Maka secara simultan atau bersamaan Pelayanan RS, Lingkungan RS, dan Fasilitas RS secara bersama-sama berpengaruh terhadap kepuasaan pasien di Ruang Rawat Inap Badan Pengelola RSUP dr Tajuddin Chalid Makassar

3) Uji R (Uji Koefisien Determinasi)

Uji ini dimaksudkan untuk mengukur seberapa jauh variabel independen mempengaruhi variabel dependen. Nilai R-Square yang besarnya 0,549 menunjukkan bahwa proporsi pengaruh variabel pelayanan RS, lingkungan RS, dan fasilitas RS terhadap variabel kepuasan pasien sebesar 54,9\%. Artinya, pelayanan, lingkungan, dan fasilitas RS memiliki proporsi pengaruh terhadap kepuasan pasien di Ruang Rawat Inap Badan Pengelola RSUP dr Tajuddin Chalid Makassar sebesar 54,9\% sedangkan sisanya yaitu 45,1\% (100\% - 54,9\%) dipengaruhi oleh variabel lain yang tidak ada di dalam model regresi linier ini.

\section{Pembahasan}

1. Kepuasan Pasien

Setelah dilakukan pengumpulan data dan analisa data yang ada maka dapat diketahui bahwa secara umum pasien di Ruang Rawat Inap Badan Pengelola RSUP dr Tajuddin Chalid Makassar mengatakan puas dengan pelayanan yang diberikan. Hal ini terlihat pada data bahwa $90 \%$ responden mengatakan puas dan hanya $10 \%$ yang tidak puas.

Kepuasan pasien merupakan suatu hal yang wajar diungkapkan oleh pasien sebagai pengguna jasa pelayanan Rumah Sakit setelah atau sementara ia menerima pelayanan. Pelayanan yang dipersepsikan baik akan memberikan rasa puas kepada pasien. Kepuasan pelanggan adalah tingkat perasaan seseorang setelah membandingkan kinerja yang dirasakan dibandingkan dengan harapannya [16]. Dengan demikian jika hasil pengumpulan data menunjukkan hasil pasien puas berarti harapan pasien terhadap pelayanan sudah sesuai dengan pelayanan yang diberikan oleh Ruang Rawat Inap Badan Pengelola RSUP dr Tajuddin Chalid Makassar.

Kepuasan seseorang dalam hal ini pasien juga dapat dipengaruhi oleh pengalaman sebelumnya terhadap pelayanan yang diberikan. Jika pelayanan yang pernah dirasakan sebelumnya berada pada level dibawah dibanding yang dirasakan saat ini juga dapat mengantar kepada kepuasan. Hal ini sesuai dengan pendapat Suciati bahwa kepuasan karena mencapai tujuan dipengaruhi oleh konsekuensi yang berasal dari dalam maupun dari luar individu [17]. Begitu pula halnya jika pasien pertama kali menerima pelayanan kesehatan, maka mereka akan mengatakan puas dengan pelayanan yang diberikan karena belum mempunyai pengalaman sebagai bahan pembanding terhadap pelayanan yang diterima. Menurut Pohan kepuasan pasien adalah suatu tingkat perasaan pasien yang timbul sebagai akibat dari kinerja layanan kesehatan yang diperolehnya setelah pasien membandingkannya dengan apa yang diharapkan. [18]

Ditinjau dari segi pendidikan responden, umumnya pendidikan responden adalah SMA $(46,7 \%)$ dan SD (35\%). Menurut hasil pengamatan peneliti, umumnya makin tinggi tingkat pendidikan maka semakin tinggi standar yang digunakan seseorang dalam menerima pelayanan sehingga tidak mudah untuk mengatakan puas terhadap pelayanan yang diberikan. Dengan demikian karena umunya responden memiliki pendidikan SMA dan SD maka dapat saja mempengaruhi tingkat kepuasan pasien terhadap pelayanan yang diberikan.

Meskipun pada umumnya pasien mengatakan puas terhadap pelayanan yang diberikan, namun ada juga yang mengatakan tidak puas terhadap pelayanan yang diberikan. Kepuasan klien atas pelayanan yang diberikan merupakan nilai subjektif terhadap kualitas pelayanan yang diberikan dan diterima oleh klien. Meskipun nilai subjektif ini sangat dipengaruhi oleh pengalaman masa lalu, pendidikan, keadaan emosional dan lingkungan, akan tetapi kepuasan klien tetap akan didasari oleh kebenaran dan kenyataan objektif yang dialami oleh klien saat menerima pelayanan di Rumah Sakit antara lain saat menerima pelayanan asuhan keperawatan dari perawat.

2. Pelayanan Rumah Sakit

Mutu keperawatan adalah proses penerapan tingkat yang terbaik untuk melaksanakan tindakan keperawatan dalam tindakan pelayanan kesehatan lainnya yang menjamin bahwa setiap klien mendapatkan pelayanan keperawatan yang bermutu tinggi sesuai dengan yang telah ditetapkan. Pelayanan Rumah Sakit merupakan suatu sistem yang terintegrasi dalam memenuhi kebutuhan pasien selama menjalani perawatan di Rumah Sakit [19]

Hasil penelitian menunjukkan bahwa penilaian responden terhadap pelayanan yang diberikan oleh Rumah Sakit umumnya menyatakan baik $(95 \%)$ dan hanya $5 \%$ yang mengatakan kurang. Pelayanan Rumah Sakit menyangkut mutu atau kualitas pelayanan yang diberikan. Mutu pelayanan kesehatan menunjuk pada tingkat kesempurnaan pelayanan kesehatan, yang disuatu pihak dapat menimbulkan kepuasan kepada setiap pasien sesuai dengan tingkat kepuasan rata-rata penduduk, serta di pihak lain tata cara penyelenggaraan sesuai dengan kode etik dan standar pelayanan profesi yang telah ditetapkan [4]. pelayanan yang tepat waktu (just in time) merupakan salah satu faktor penting yang perlu dipertimbangkan dalam peningkatan kualitas pelayanan. Sedangkan pelayanan yang sangat lama dan antrian yang panjang tidak hanya memberikan efek ketidakpuasan bagi para pasien tetapi juga memberikan efek buruk bagi keselamatan pasien dimana hal ini sangat mempengaruhi outcome klinis pasien terutama pada pasien yang mengalami keadaan kritis [

Jurnal Kesehatan Masyarakat, Vol. 07, No. 2, 2021: 90-100 
Jika pelayanan yang diberikan sudah sesuai dengan harapan yang di inginkan oleh pasien maka respon yang akan diberikan pasien dapat berupa pernyataan penilaian yang baik terhadap pelayanan yang diberikan. Jika pelayanan yang diberikan tidak sesuai dengan yang di inginkan oleh penerima jasa layanan maka pelayanan dianggap kurang.

\section{Lingkungan Rumah Sakit}

Hasil penelitian menunjukkan bahwa $75 \%$ responden mengatakan bahwa lingkungan Rumah Sakit sudah baik. Hal ini menunjukkan bahwa secara umum pasien menganggap lingkungan pelayanan Ruang Rawat Inap Badan Pengelola RSUP dr Tajuddin Chalid Makassar sudah baik dan sesuai dengan harapan pasien.

Lingkungan Rumah Sakit yang baik akan memberikan kenyamanan bagi pasien dalam menerima pelayanan selama berada di Rumah Sakit. Kondisi lingkungan yang kondusif menumbuhkan rasa puas terhadap pelayanan yang diberikan dan dapat membentuk mempercepat proses penyembuhan.

Dalam penelitian ini masih ditemukan juga responden yang mengatakan lingkungan Rumah Sakit kurang baik. Persepsi setiap orang terhadap standar lingkungan Rumah Sakit berbeda-beda bergantung pada pemahaman dan pengalaman. Hal ini searah dengan pendapat yang bahwa kepuasan karena mencapai tujuan dipengaruhi oleh konsekuensi yang berasal dari dalam maupun dari luar individu [17]

4. Fasilitas Rumah Sakit

Setelah dilakukan pengumpulan data maka diketahui bahwa terdapat 76,7 \% pasien mengatakan bahwa fasilitas Rumah Sakit cukup. Fasilitas merupakan alat bantu suatu pemberi layanan seperti Rumah Sakit dalam memberikan pelayanan kepada pengguna jasa pelayanan dalam hal ini pasien.

Ketersediaan fasilitas pelayanan memudahkan pasien menerima layanan yang akurat sesuai dengan masalah yang dihadapi. Pelayanan kesehatan dikatakan bermutu bila pelayanan kesehatan tersebut tersedia di masyarakat. Selain fasilitas tentu dibutuhkan juga kenyamanan dan keamanan dalam menggunakan fasilitas tersebut. Kenyamanan yang dimaksud disini tidak hanya yang menyangkut fasilitas yang disediakan, tetapi terpenting lagi menyangkut sikap serta tindakan para pelaksana ketika menyelenggarakan pelayanan kesehatan. [4]

Persepsi pasien terhadap kecukupan fasilitas pelayanan Rumah Sakit tidak terlepas dari pengetahuan dan pengalaman yang dirasakan dalam menerima pelayanan kesehatan. Pasien yang pernah menerima pelayanan Rumah Sakit dengan fasilitas yang canggih akan menganggap pelayanan kurang jika fasilitas kurang. Bagi pasien yang tidak mengetahui banyak tentang fasilitas dan peralatan kesehatan yang terus berkembang akan menganggap cukup fasilitas yang ada pada saat dirawat. Hal inilah yang membuat masih ditemukan juga responden yang mengatakan bahwa ketersediaan fasilitas masih kurang.

5. Kepuasan Pasien di Ruang Rawat Inap Badan Pengelola RSUP dr Tajuddin Chalid Makassar.

Setelah dilakukan pengumpulan data, analisa data dan pengujian hipotesis dengan menggunakan statistik untuk menilai hubungan antara pelayanan Rumah Sakit dengan kepuasan pasien didapatkan nilai $\mathrm{p}=0,000$ dengan $\alpha=0,05$ sehingga disimpulkan nilai $\mathrm{p}<\dot{\alpha}$, maka ada hubungan yang bermakna antara pelayanan Rumah Sakit dengan kepuasan pasien.

Berdasarkan data diketahui bahwa $90 \%$ pasien yang mengungkapkan pelayanan baik juga merasa puas dengan pelayanan yang diberikan. Pada umumnya pasien menilai bahwa pelayanan di Ruang Rawat Inap Badan Pengelola RSUP dr Tajuddin Chalid Makassar sudah baik dan pasien juga pada umumnya mengatakan puas dengan pelayanan yang diberikan. Kepuasan merupakan penilaian yang bersifat subjektif dan penilaian tersebut tentunya berdasarkan persepsi terhadap pelayanan yang diberikan.

Kepuasan pasien dapat dipengaruhi oleh kenyamanan pelayanan yang diberikan. Kenyamanan yang dimaksud disini tidak hanya yang menyangkut fasilitas yang disediakan, tetapi terpenting lagi menyangkut sikap serta tindakan para pelaksana ketika menyelenggarakan pelayanan kesehatan. Jika pasien merasa nyaman dengan sikap dan perilaku petugas baik perawat maupun penunjang maka tentu pasien akan mengatakan puas dengan pelayanan yang diberikan [4]. Kepuasan karena mencapai tujuan dipengaruhi oleh konsekuensi yang berasal dari dalam maupun dari luar individu [17]

Faktor lain yang dapat mempengaruhi kepuasan pasien adalah faktor lingkungan Rumah Sakit sebagaimana telah dijelaskan diatas bahwa Kepuasan pasien terhadap pelayanan kesehatan yang diberikan dipengaruhi oleh kepuasan terhadap pelayanan (medis, keperawatan, gizi, laboratorium, radiologi, administrasi), lingkungan dan fasilitas yang tersedia, [4]. Hasil uji statistik untuk menilai hubungan lingkungan Rumah Sakit dengan kepuasan pasien didapatkan nilai $\mathrm{p}=0,001$ dengan $\alpha=0,005$. Dengan demikian $\mathrm{p}<\dot{\alpha}$, maka terdapat hubungan yang bermakna antara lingkungan Rumah Sakit dengan kepuasan pasien.

Dalam pengumpulan data ditemukan bahwa $73 \%$ pasien yang berpendapat lingkungan Rumah Sakit baik juga menyatakan puas dengan pelayanan. Lingkungan Rumah Sakit yang nyaman akan memberikan ketenangan dan menumbuhkan rasa aman pasien selama dirawat Kondisi lingkungan yang baik membuat pasien merasa harapannya terhadap pelayanan bisa didapatkan sebagaimana yanng di inginkan sehingga ia merasa terpuaskan. 
Kepuasan pelanggan adalah perasaan senang seseorang sebagai hasil dari perbandingan antara persepsi yang dirasakan dan yang diharapkan [20].

Dalam pengumpulan data juga ditemukan responden yang menyatakan lingkungan Rumah Sakit baik tetapi tidak puas dengan pelayanan yang diberikan Rumah Sakit. Pernyataan kepuasan dapat dipengaruhi oleh banyak hal bukan hanya karena faktor lingkungan.

Faktor fasilitas juga dapat memberikan pengaruh terhadap kepuasan pasien dalam menerima pelayanan kesehatan di Rumah Sakit. Hasil uji statistik untuk menilai hubungan fasilitas dengan kepuasan pasien didapatkan nilai $\mathrm{p}=0,008$ dengan $\dot{\alpha}=0,05$. Dengan demikian $\mathrm{p}<\dot{\alpha}$ maka, ada hubungan yang bermakna antara ketersediaan fasilitas Rumah Sakit dengan kepuasan pasien.

Dalam penelitian ini fasilitas yang dimaksudkan adalah ketersediaan peralatan dasar yang dibutuhkan pasien selama perawatan. Ketersediaan fasilitas membuat pasien akan merasa semua kebutuhannya terakomodir sebagaimana yang diharapkan yang pada akhirnya juga membuat pasien merasa puas dengan pelayanan yang diberikan.

Kepuasan pada setiap orang berbeda-beda apalagi kalau menyangkut pelayanan di Rumah Sakit. Pengalaman dirawat di Rumah Sakit yang berbeda akan memunculkan persepsi yang berbeda terhadap pelayanan dari setiap Rumah Sakit. Hal tersebut dapat pula mempengaruhi penilaian seseorang terhadap pelayanan yang diberikan oleh Rumah Sakit.

Pada umumnya pasien yang dirawat di Ruang Rawat Inap Badan Pengelola RSUP dr Tajuddin Chalid Makassar adalah masyarakat yang juga berasal dari Makassar, Kabupaten Maros dan kabupaten lain. Dengan demikian karakteristik pasien yang dirawat Ruang Rawat Inap Badan Pengelola RSUP dr Tajuddin Chalid Makassar tidak begitu bervariasi sehingga tuntutan dari pasien juga tidak begitu banyak. Disamping itu tingkat pendidikan masyarakat yang masih rendah juga membuat standar kepuasan pasien tidak terlalu sulit untuk dicapai. Kepuasan adalah tingkat keadaan yang dirasakan seseorang yang merupakan hasil dari membandingkan penampilan atau outcame produk yang dirasakan dalam hubungannya dengan harapan seseorang. Dengan demikian tingkat kepuasan adalah suatu fungsi dari perbedaan antara penampilan yang dirasakan dan harapan [20]

\section{KESIMPULAN}

Setelah dilakukan penelitian untuk mengetahui faktor-faktor yang mempengaruhi kepuasan pasien yang dirawat di Ruang Rawat Inap Badan Pengelola RSUP dr Tajuddin Chalid Makassar dengan metode penelitian deskriptif korelatif, menunjukkan adanya hubungan yang bermakna antara pelayanan, lingkungan dan ketersediaan fasilitas Rumah Sakit dengan kepuasan pasien di Ruang Rawat Inap Badan Pengelola RSUP dr Tajuddin Chalid Makassar. Secara umum pasien yang dirawat di Ruang Rawat Inap Badan Pengelola RSUP dr Tajuddin Chalid Makassarmengatakan puas dengan pelayanan yang diberikan.

\section{UCAPAN TERIMA KASIH}

Ucapan terima penulis ucapkan kepada Bapak dr.I Gusti Lanang Suartana Putra, MM, MARS selaku Direktur Utama RSUP dr tadjuddin Chalid Makassar telah memberi ijin melaksanakan penelitian dan teman-teman yang ada di RSUP dr tadjuddin chalid makassar yang telah membantu wawancara pasien dan megumpul kuesiner pada pasien serta semua pihak yang telah memberikan dukungan kepada penulis.

\section{DAFTAR RUJUKAN}

[1] R, A, Listiyono, "Studi Deskriptif Tentang Kuaitas Pelayanan di Rumah Sakit Umum Dr. Wahidin Sudiro Husodo Kota Mojokerto Pasca Menjadi Rumah Sakit Tipe B” Kebijakan dan Manajemen Publik, Volume 1, Nomor 1, PP, 1-7, 2015.

[2] M, Dewi, "Pengaruh Kualitas Pelayanan terhadap Kepuasan Pasien Pengguna BPJS pada Rumah Sakit Rehabilitasi Medik Kabupaten Aceh Timur” JURNAL MANAJEMEN DAN KEUANGAN, VOL.5, NO.2, PP, 535-544, 2016.

[3] T, R, P, Lestari, "Pelayanan Rumah Sakit bagi Masyarakat Miskin (Studi Kasus di Enam Wilayah Indonesia)” KESMAS, Jurnal Kesehatan Masyarakat Nasional Vol. 5, No. 1, PP, 9-16, 2010.

[4] A, Azrul, "Pengantar Administrasi Kesehatan", Jakarta, Binarupa Aksara, 2000.

[5] Ira Setyaningsih, "Analisis Kualitas Pelayanan Rumah Sakit Terhadap Pasien Menggunakan Pendekatan Lean Servperf (Lean Service Dan Service Performance) (Studi Kasus Rumah Sakit X)” Spektrum Industri, Vol. 11, No. 2, PP, 117 - 242. 2013. 
[6] D, W, Astari, A, Noviantani and R, Simanjuntak, "Kepuasan Pasien terhadap Mutu Pelayanan Keperawatan di Era Pandemi Covid-19 di Rumah Sakit Mata Cicendo", Journal of Hospital Accreditation, Vol 03, 1, PP, 34-38, 2021.

[7] O, Dewi, Raviola and N, P, Sari, “Analisis Survei Kepuasan Pelanggan Terhadap Mutu Pelayanan Di Rumah Sakit Jiwa Tampan Provinsi Riau" KESKOM, Vol 7(1) PP, 117-123, 2021

[8] A, Pasalli and A, A, Patattan, "Hubungan Mutu Pelayanan Kesehatan dengan Kepuasan Pasien di Rumah Sakit Fatima Makale di Era New Normal” Jurnal Keperawatan Florence Nightingale (JKFN) Vol. 4, No. 1, PP. 14-19, 2021.

[9] S, M, Sari, "Pengaruh Kualitas Pelayanan Dan Kepuasan Pasien Terhadap Loyalitas Pasien (Studi Pada Rumah Sakit Bhayangkara Tk Ii Sartika Asih Bandung)" Jurnal Economix , Volume 9 Nomor 1, PP, 61-72, 2021

[10] D, Kartikasari, A, Dewanto, and F, Rochman, "Pengaruh Kulaitas Layanan terhadap Kepuasan dan Kepercayaan di Rumah Sakit Bunda Kandangan Surabaya” Jurnal Aplikasi Manajemen, Vol 12 No 3, PP, 454-463, 2014.

[11] Chriswardani Suryawati, Dharminto, Zahroh Shaluhiyah, "Penyusunan Indikator Kepuasan Pasien Rawat Inap Rumah Sakit Di Provinsi Jawa Tengah”, Jurnal Manajemen Pelayanan Kesehatan, Volume 09 No 04, PP, 177 - 184, 2006.

[12] Azwar, Azrul, and P, Joedo, "Metodologi Penelitian Kedokteran dan Kesehatan Masyarakat", Jakarta, Binarupa Aksara, 2003.

[13] Nursalam and Pariani, "Pendekatan Praktis Metodologi Riset Keperawatan”, Jakarta, Rineka Cipta, 2001.

[14] N, Soekidjo, "Pendidikan dan Perilaku Kesehatan", Jakarta, Rineka, 2000.

[15] Sugiyono, "Statistika Untuk Penelitian", Bandung, CV Alfabeta, 2007.

[16] P, Kotler, and K, K, Lane, "Manajemen Pemasaran”, Edisi Keduabelas, Jakarta, Indeks, 2007.

[17] X, Suciati “Teori Belajar dan Motivasi”, Jakarta, Direktorat Jenderal Pendidikan Tinggi, 2003.

[18] A, Pranatha, R, M, Sudirman, N, Novitasari, "Faktor-Faktor Yang Berhubungan Dengan Kepuasan Pasien Terhadap Pelayanan Keperawatan Di Puskesmas Rawat Inap Se-Kabupaten Kuningan Tahun 2017, Jurnal Skolastik Keperawatan Volume 4 No1 PP, 1-9. 2018.

[19] D, A, Gillies, "Manejemen Keperawatan Suatu Pendekatan Sistem”, Philadelphia : WB Sounders Company, 1980.

[20] F, Rangkuti "Measuring Customer Satisfaction Gaining Customer Relation Strategy", Jakarta, Gramedia Pustaka Utama, 2003.

[21] B, Eninurkhayatun, A, Suryoputro, E, Y, Fatmasari, “Analisis Tingkat Kepuasan Pasien Terhadap Kualitas Pelayanan Rawat Jalan Di Puskesmas Duren Dan Puskesmas Bergas Kabupaten Semarang Tahun 2017”, JURNAL KESEHATAN MASYARAKAT (e-Journal) Volume 5, Nomor 4, PP, 33-42, 2017.

[22] E, Nurcahyanti, and H, Setiawan, "Studi hubungan antara mutu pelayanan kesehatan dengan kepuasan Pasien di unit pelayanan rawat inap rumah sakit umum daerah bhakti Dharma husada Kota Surabaya", Jurnal manajemen kesehatan yayasan rs dr. Soetomo, vol. 3 no. 1, PP, 15- 30, 2017.

[23] N, Aisyah, "Quality of Life and Women Empowerment in Central Sulawesi, Sociology Study Program, Faculty of Social and Political Sciences" Journal of Asian Multicultural Research for Social Sciences Study Vol. 2 No. 1, PP, 036-044, 2021.

[24] V, Sesrianty, R Machmud, and F, Yeni, “Analisa Kepuasan Pasien Terhadap Mutu Pelayanan Keperawatan”, Jurnal Kesehatan Perintis (Perintis's Health Journal) valume 6 No 2, PP, 116-126. 2019

[25] N, Prihartini, dkk. "Kepuasan Pasien Rawat Jalan terhadap Pelayanan Kefarmasian di Rumah Sakit dan Puskesmas di 11 Provinsi di Indonesia” Jurnal Kefarmasian Indonesia, Vol.10 No.1, PP, 42-49, 2020 